\title{
A Study of Korean Hearing Aid Satisfaction Survey Based on MarkeTrak VIII
}

\author{
Sangik Sim', Junghak Lee², Jinsook Kim ${ }^{1,3}$ \\ 'Department of Speech Pathology and Audiology, Graduate School, Hallym University, Chuncheon, Korea \\ ${ }^{2}$ Department of Audiology and Speech-Language Pathology, Hallym Univesity of Graduate Studies, Seoul, Korea \\ ${ }^{3}$ Division of Speech Pathology and Audiology, Research Institute of Audiology and Speech Pathology, College of Natural Sciences, Hallym University, \\ Chuncheon, Korea
}

Received: October 28, 2019 Revised: November 28, 2019

Accepted: December 19, 2019

Correspondence:

Jinsook Kim, PhD

Department of Speech Pathology and Audiology, Graduate School, Hallym University, 1 Hallymdaehak-gil, Chuncheon 24252, Korea

Tel: +82-33-248-2213

Fax: +82-33-256-3240

E-mail: jskim@hallym.ac.kr

\begin{abstract}
Purpose: The aim of this study was to survey the satisfaction of hearing aid users in Korea. The questionnaire was designed to find out not only the satisfaction of wearing hearing aid but also the various viewpoints about the hearing aid itself of its wearers. Methods: A total of 118 subjects including 72 males and 46 females completed the survey from 28 hearing aids centers. The questionnaire was divided into two parts. The first part contained the audiological information reported by the experts and the other part included about the information of hearing aid performance, listening environments and related services reported by the hearing aid users. Results: Overall satisfaction rate of hearing aid was $64.4 \%$. About $84 \%$ of the subjects answered that the hearing aid made their quality of life improved. The most satisfied function of the hearing aid was 'overall comfort,' the most satisfied sound quality was 'improved hearing ability,' the most satisfied listening environments was 'one-to-one conversation,' and the most satisfied service quality was 'kindness of the staffs.' The most important listening situation they thought was 'communication with cell phone.' The proportion of using customized hearing aid was $77.9 \%$, bilateral fitting rate was $62.4 \%$ and average purchasing price was 1,820,000 won per a unit. Conclusion: The overall hearing aid satisfaction rate (64.4\%) was lower than USA (81\%) and Germany (76\%) but higher than Japan (38\%). In Korea, the comprehensive study for the hearing aid market, specific satisfaction viewpoints of the hearing aid wearers and the status of non-wearers who have hearing loss should be needed for improving the user's hearing aid satisfaction rate in the future.
\end{abstract}

Key Words: Hearing aid satisfaction, Hearing aid, Hearing aid market, Hearing aid adoption.

\section{INTRODUCTION}

의학적 기술의 발달로 인간의 수명은 증가하고 있는 반면 저 출산 현상으로 인구의 고령화는 점차 심각해지고 있다(Lee \& Lee, 2010). 그에 따른 여러 가지 사회적 문제들이 나타나고 있 는데, 그중 하나가 노인성 난청 인구의 증가이다. 노인성 난청 인구의 증가는 보청기의 사용도 증가하게 하였는데, 이는 과거 의 제한적인 청각 보조기기의 종류, 불만족스러운 기능, 보청기 및 청각 보조기기에 대한 사회적인 편견 등 여러 가지 문제점들 이 보청기 기술의 발전과 보청기에 대한 대중의 인식이 긍정적 으로 개선되어 보청기 사용에 대한 동기가 증가하고 있기 때문

(c) This is an Open Access article distributed under the terms of the Creative Commons Attribution Non-Commercial License (https://creativecommons.org/licenses/by-nc/4.0) which permits unrestricted non-commercial use, distribution, and reproduction in any medium, provided the original work is properly cited.
이다(Sawyer et al., 2019). 이러한 현상은 최근 국내에서도 나 타났는데, 특히 노인층에서 청력손실에 대한 견해와 보청기에 대한 부정적 시각이 개선되고 있다고 보고하고 있다(Yoo et al., 2012).

보청기는 청력손실의 보상을 통해 듣기 능력의 향상과 개인 의 삶의 질을 개선하는 데 많은 도움을 주고 있는데(Erler \& Garstecki, 2002), 이러한 보청기의 긍정적 역할을 기대하기 위 해서는 적절한 보청기 증폭과 적합이 필수적이다. 보청기의 증 폭과 적합의 적절성에 대한 평가를 위해서는 적합의 확인(verification) 방법으로 보청기 착용 전후 방음실에서의 청력역치 레벨과 어음인지도, 전기 음향적 특성 또는 고막 근처에서의 음 향이득을 측정하는 방법 등이 적용된다. 그러나 객관적 적합의 확인 방법으로 평가한 내용이 우수하다 할지라도 그 결과가 보 청기 사용자의 주관적 만족도와 비례하지는 않는다. 따라서 보 
청기 착용자에게 실생활에서 부딪치는 다양한 청취 환경에서 보청기의 만족도를 직접 확인하는 설문 내용으로 만족도를 구 체적으로 평가하여 개인에 맞춘 보청기 만족도를 높일 수 있는 방법을 강구하여야 한다(Jorgensen, 2016).

기존의 보청기 만족도를 파악하는 여러 설문지는 보청기의 기능에 대한 평가, 청취 상황별 효과, 심리·정서적인 요인의 평 가, 일상생활의 난청으로 인한 어려움이나 불편함 등에 대한 평 가를 포함하여 적게는 7 개 항목부터 많게는 60 여 개 항목까지 검사하는 다양한 종류가 사용되고 있다. 그러나 이러한 설문지 들은 공통적으로 다음과 같은 제한점이 있다. 첫째, 개인의 의 견에 국한된 평가이고, 둘째, 실생활에서 보청기 사용에 대한 구체적인 상황을 파악하는 내용이 미비하고, 셋째, 보청기의 종 류, 타입, 기술 수준 등에 대한 평가가 포함되어 있지 않고, 넷 째, 설문지를 사용하는 각 사회의 문화, 정서, 경제적 영향 등을 반영하지 못하고 있다는 점이다(Wong et al., 2003). 따라서 좀 더 구체적으로 보청기의 만족도를 평가하기 위해서 동시대의 문제점을 포함하여 이러한 제한점을 개선할 수 있는 설문지가 필요하다. 또한 이러한 내용들을 지속적으로 조사하고 체계적 으로 분석하여 그 결과를 해당 사회에 반영할 수 있어야 한다. 미국이나 유럽은 이러한 기존의 보청기 만족도의 설문지에 대 한 제한점을 이미 보완하여 구체적인 보청기 만족도를 평가할 수 있는 체계적 만족도의 조사와 분석 시스템이 구축되어 있다. 예를 들면 대표적으로 35년간 꾸준히 보청기 만족도를 보고하 고 있는 미국의 MarkeTrak 보고서와, 유럽과 아시아 국가의 조 사 및 분석 시스템인 EuroTrak 등이 있다. 특히 MarkeTrak 보 고서는 9권 이후 이전의 우편과 방문 조사 방식에서 온라인 조사 시스템으로 보청기 시장 조사, 보청기 착용자 만족도 조사, 보청 기 비착용자 현황으로 구성된 설문 내용을 체계적으로 조사하고 분석하는 구조를 완성하였다(Abrams \& Kihm, 2015; EHIMA, 2019).

이러한 구체적이고 체계적인 보청기 만족도 조사 시스템은 전 세계에서 고령화 속도가 가장 빠르고 노인성 난청 인구가 많 을 것으로 추정할 수 있는 우리나라에서는 구현되지 못하고 있 다(Korea Centers for Disease Control and Prevention, 2013). 그러나 증가하는 노인성 난청 인구를 고려할 때, 우리나라에서 도 지속적이고 체계적인 보청기 만족도 조사 분석을 통해 그 내 용을 실질적으로 활용할 수 있는 시스템을 마련하여 보청기 만 족도를 향상시켜야 할 필요성이 있다. 그런 시스템을 구축하기 위하여 본 연구는 MarkeTrak의 최근 자료를 기반으로 국내의 보청기 시장과 만족도 현황을 구체적으로 파악할 수 있는 설문 조사 자료를 구성하고 분석하고자 하였다. 더 나아가 분석 내 용을 MarkeTrak과 EuroTrak의 결과와 비교하여 국내 사용에 적절한 보청기 만족도 조사 체계를 구성하는 기반을 구축하고
자 한다. 또한 이러한 결과는 국내 고유한 문화와 정서를 반영 하여 국내 보청기 시장 및 만족도 조사 분석 결과를 제시하여 우리나라 보청기 시장의 환경을 개선하고 만족도를 높일 수 있 을 것이다.

\section{MATERIALS AND METHODS}

\section{연구 대상}

전국의 28 개 보청기센터, 경북 6 개소, 서울 5 개소, 경기 3 개 소, 부산 · 경남·광주·전남 각 2 개소, 강원 · 대구· 울산·충북. 대전·제주 각 1 개소에 내방한 보청기 착용자 중 연구의 목적에 동의하는 고객을 대상으로 서면 작성을 통해 보청기 만족도 설 문조사를 실시하였다. 총 응답자는 118 명이었으며, 이 중 남성은 72명, 여성은 46명이었다. 응답자의 평균 연령은 69.03세[standard deviation (SD): 15.26세]였고, 순음역치 평균은 오른쪽 귀가 $65.66 \mathrm{~dB} \mathrm{HL}$ (SD: $15.27 \mathrm{~dB} \mathrm{HL}$ ), 왼쪽 귀가 $64.10 \mathrm{~dB}$ $\mathrm{HL}$ (SD $18.66 \mathrm{~dB}$ HL)이었다. 어음인지도(word recognition score)검사 결과는 오른쪽 귀가 55.53\%(SD: 23.01\%), 왼쪽 귀 가 $57.45 \%$ (SD: $24.19 \%$ )였다. 청력손실의 형태는 하강형이 $55.6 \%$ 로 가장 많았으며, 수평형이 $39.4 \%$, 상승형과 산형이 각 각 $3.0 \%$ 와 $2.0 \%$ 로 나타났다.

\section{설문지 제작}

본 연구에 사용된 설문지는 MarkeTrak 8권의 설문 내용을 기반으로 하고 국내 보청기 착용자들에게 필요한 내용을 포함 하고 불필요한 내용을 제거한 후 전체 설문지를 재구성하여 사 용하였다. 예를 들면 MarkeTrak 8권의 설문지는 보청기 착용 자가 쉽게 응답하기 어려운 항목인 보청기 종류, 타입, 가격대, 청력손실의 정도 등을 포함하고 있는데, 재구성한 설문지는 이 러한 부분을 국내 보청기 착용자가 작성하기 어려워하여 청각 전문가가 작성하도록 하였고, 보청기 착용과 관련된 만족도 부 분은 보청기 착용자가 직접 작성하도록 두 부분으로 설문지를 구성하였다. 청각전문가가 직접 작성하는 부분은 인적 사항, 청 각학적 사항, 보청기 관련 사항의 세 부분으로 구성하여 난청 의 정도와 유형, 어음인지도검사 결과, 보청기 타입, 브랜드 및 모델, 보청기 가격대 등을 기록하도록 11 개 항목으로 구성하였 다. 보청기 착용자가 작성하는 부분은 여러 청취 환경에서의 보 청기의 만족도, 보청기를 통한 삶의 질 개선 정도, 청각전문가 의 서비스에 대한 만족도 등을 파악할 수 있는 150 개 항목의 구체적인 내용을 확인할 수 있는 설문으로 구성하였다. 본 설문 지의 내용이 방대하고 보청기 만족도 평가와 직접적 관련이 없 는 항목도 일부 포함되었고, 각 항목별로 설문 응답자 수도 일 정치 않다. 따라서 결과는 전체 항목 중 보청기 만족도와 직접 


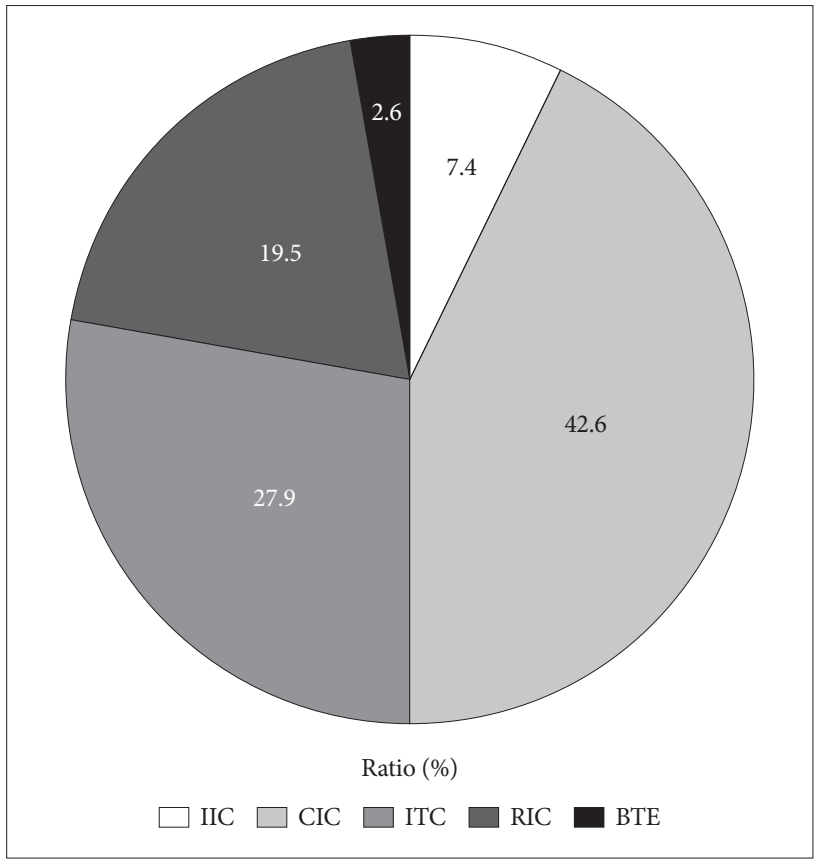

Figure 1. The type of hearing aids which the respondents use. IIC: Invisible In the Canal, CIC: Completely In the Canal, ITC: In The Canal, RIC: Receiver In the Canal, BTE: Behind The Ear.

적으로 관련된 내용을 발췌하여 정리하였다.

\section{RESULTS}

설문지 조사 결과 73명(62.4\%)이 보청기를 양이에 착용하였 다고 응답하였다. 총 118 명의 응답자의 보청기를 착용한 총 귀 수는 190귀였다. 보청기를 착용한 190귀의 보청기 타입은 초소 형 고막형(Invisible In the Canal, IIC)이 7.4\%(14귀), 고막형 (Completely In the Canal, CIC)이 42.6\%(81귀), 외이도형(In The Canal, ITC)이 27.9\%(53귀), 외이도내수화기형(Receiver In the Canal, RIC)이 19.5\%(37귀), 귀걸이형(Behind The Ear, BTE)이 2.6\%(5귀)였다(Figure 1). 보청기 기술 수준의 분류는 제조회사마다 달라 권장 소비자 가격표를 기준으로 분류하였는 데, 600만원대는 최고급형, 400 500만원대는 고급형, 300 400 만원대는 기본형, 300 만원 이하대는 경제형으로 나누어 분류하 였다. 이러한 분류 기준으로 착용한 보청기의 기술 수준을 파 악하였을 때 최고급형 보청기는 $12.3 \%(23$ 귀), 고급형 보청기는 $11.8 \%$ (22귀), 기본형 보청기는 $39.0 \%$ (73귀), 경제형 보청기는 $36.9 \%$ (69귀)였고, 착용한 보청기의 개당 평균 가격은 182 만원 이었다(Figure 2).

청력검사 결과와 무관하게 본인이 느끼는 듣기의 어려움에 대 한 응답은 양측 모두 듣기에 어려움이 있다고 답한 경우가 $83.5 \%$ (96명), 한쪽 귀만 듣기에 어려움이 있다고 응답한 경우가 $16.5 \%$

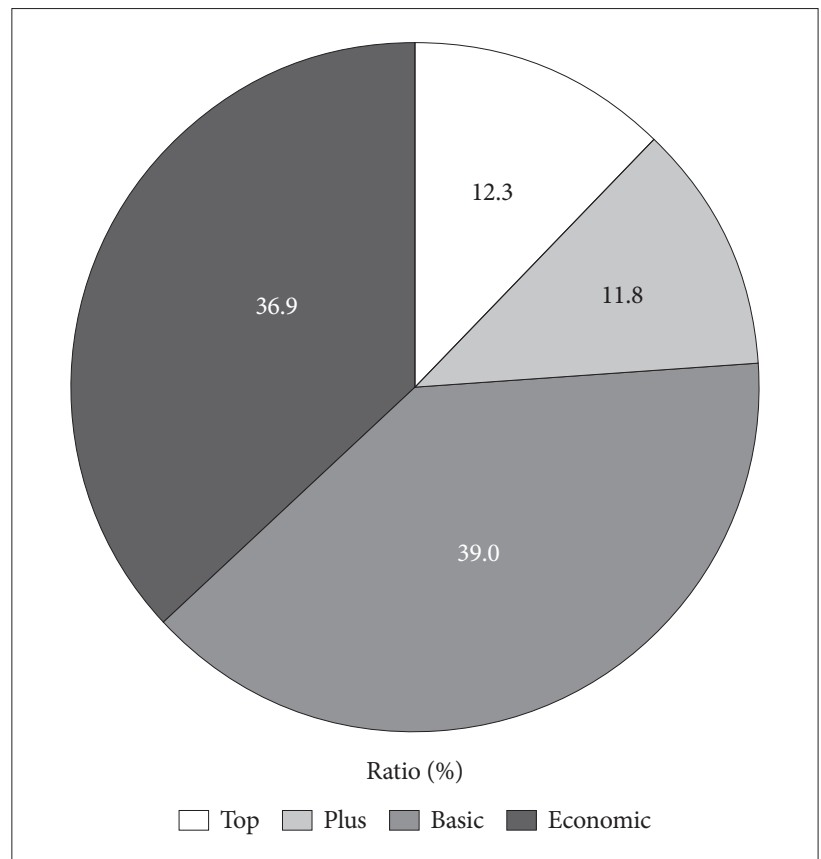

Figure 2. The classification of the technology level of the hearing aids. Top: over $6,000,000$ won, Plus: $4,000,000-5,000,000$ won, Basic: 3,000,000-4,000,000 won, Economic: below 3,000,000 won. Classified by recommanded enduser price.

(19명)였다. 보청기를 착용하지 않고 듣기에 어려움이 있는 정도 를 묻는 질문에 경도 난청으로 응답한 경우가 $3.5 \%$ (4명), 중도 난청으로 응답한 경우가 $50.0 \%$ (56명), 고도 난청으로 응답한 경 우가 39.9\%(45명), 심도 난청으로 응답한 경우가 7.1\%(8명)였다.

현재 착용하고 있는 보청기를 구매한 시기는 1년 이내가 $21.2 \%$ (25명), 1년 이상 3년 미만이 51.7\%(61명), 3년 이상 5년 미 만이 22.0\%(26명), 5년 이상이 5.1\%(6명)였다. 보청기를 착용한 기간은 최소 1 개월부터 최대 35 년까지 다양하게 나타났는데, 평균은 6.3년(SD: 6.53년)이었다. 보청기를 사용하기 시작한 이 후로 구매한 보청기 개수는 평균 2.65개로 나타났으며, 가장 많 이 구매한 경우는 10 개로 보청기 착용 연수가 35 년으로 응답한 응답자와 동일인이 가장 많은 보청기를 구매한 것으로 나타났 다. 보청기 착용자는 보청기를 구매하기 위해 평균 1.91회를 보 청기센터나 청각전문가를 방문하는 것으로 나타났으며, 구매 결정을 위해 가장 많이 방문한 경우는 10 회였다. 보청기를 구매 한 장소는 보청기센터가 $90.0 \%(104$ 명), 개인 이비인후과가 $4.3 \%$ (5명), 대학병원 이비인후과가 $3.4 \%$ (4명), 의료기기상과 안 경점 내 보청기 취급소와 그 외 기타가 각각 $0.86 \%(1$ 명)씩으로 나타났다. 그러나 본 연구는 보청기센터의 내방 고객을 대상으 로 하였기 때문에 편중된 비율이 나타날 수 있는 한계점이 있 다. 보청기를 구매할 때 정부의 보조금 지원으로 구매한 경우 는 49.1\%(57명)였고, 보조금을 지원받은 평균 횟수는 1.35 회로 나타났으며, 가장 많이 지원받은 횟수는 4회였다. 
현재 착용하고 있는 보청기의 만족도는 매우 만족이 $10.2 \%$ (12명), 만족이 54.2\%(64명), 보통이 29.7\%(35명), 불만족이 $4.2 \%$ (5명), 매우 불만족이 $1.7 \%$ (2명)인 것으로 나타나 전반적으 로 $64.4 \%$ 의 만족도를 보였다. 하루에 보청기를 착용하는 평균 시간은 8시간 이상 착용자가 78.8\%(93명)로 가장 많았으며, 6시 간 미만 착용자가 $12.7 \%(15$ 명), 4시간 미만 착용자가 $5.9 \%$ (7명), 2시간 미만 착용자가 $1.7 \%$ (2명), 1 시간 미만 착용자가 $0.8 \%$ (1명) 로 나타났다. 주변 사람에게 보청기를 권유할 의도와 현재 구 매한 센터를 추천할 의향에 대한 질문에는 각각 $90.6 \%$ (106명) 와 88.9\%(104명)가 ‘예’라고 응답하였다. 보청기가 전반적인 삶 의 질을 향상시키는 데 도움을 주었는지에 대한 조사에서 '항 상 그렇다'라고 응답한 경우가 35.6\%(42명), '대부분'으로 응답 한 경우가 48.3\%(57명), ‘때때로’라고 응답한 경우가 $15.3 \%(18$ 명), '전혀 도움이 안 됨으로 응답한 경우가 $0.84 \%(1$ 명)로 나타 나 83.9\%가 긍정적으로 삶의 질이 개선되었다고 평가하여 보청 기의 전반적인 만족도인 $64.4 \%$ 보다도 더 높게 나타났다.

보청기를 착용하고 사회적으로 당황스러운 일을 당하거나 놀림이나 거부를 당한 적이 있는지에 대한 질문에 '전혀 없음으 로 답한 경우가 53.9\%(63명)로 가장 많았고, '때때로’로 응답한 경우가 39.3\%(46명), '대부분'과 '항상'으로 응답한 경우가 각각 $3.4 \%$ (4명)로 $46.1 \%$ 가 보청기 착용에 대해 사회로부터 부정적 시각을 경험한 것으로 나타났다.

보청기를 처음 구매하도록 영향을 준 요인에 대해 다중적으 로 응답하도록 하였을 때, '본인 스스로 청력이 나빠졌다고 느 껴서'가 56.8\%(67명)로 가장 많이 응답하였고, '배우자 및 가족 의 권유'가 $44.9 \%$ (53명), '이비인후과 의사의 권유'가 $22.0 \%$ (26 명), '청각전문가'의 권유가 $13.6 \%(16$ 명), 'TV/라디오/신문/잡지 광고'가 3.4\%(4명), '난청에 관한 기사나 책자'가 2.5\%(3명), '인 터넷 광고'가 $1.7 \%(2$ 명), 기타 의견이 $5.9 \%$ (7명)였다. 기타 요인 으로는 이웃사람의 권유, 직장 동료의 권유, 사고로 인한 청력 손실 등의 답변 등이 있었다. 앞으로 보청기를 구매할 경우 현 재 착용하고 있는 보청기와 동일한 브랜드의 제품을 구매할 의 향에 대해서는 '그렇다'는 응답이 80.3\%(94명)로 가장 많았고, '모름'이 17.1\%(20명), '아니오'가 2.6\%(3명)였다.

현재 착용하고 있는 보청기가 고장난 횟수를 묻는 질문에 고 장난 적이 없다고 응답한 경우가 52.2\%(60명)로 가장 많았고, 2 3회가 21.7\%(25명), 1회가 15.7\%(18명), 4 5회가 7.8\%(9명), 6 회 이상이 2.6\%(3명) 순으로 응답하였다. 고장에 대한 수리 서 비스에 대해서는 $93.6 \%$ 가 만족하는 것으로 나타났다.

최근 많이 사용하고 있는 무선 액세서리의 사용 여부를 묻 는 질문에 $13.8 \%$ (16명)만이 무선 액세서리를 사용하고 있는 것 으로 응답하였는데, 이들 중 사용하고 있는 무선 액세서리의 종류를 모두 선택하도록 하는 다중 응답이 가능한 질문에 스
마트폰 앱 6명, 휴대전화 무선 수신기 5명, 무선 리모콘과 TV 무선 수신기 사용이 각각 3 명인 것으로 나타났다. 응답자 중 1명 은 스마트폰 앱과 휴대전화 무선 수신기를 동시에 사용하고 있 었다. 이러한 무선 액세서리의 사용 빈도는 ‘하루에 두세 번' 정 도가 31.3\%(5명)로 가장 많았고, 그 다음이 '하루에 많이'가 $25.0 \%(4$ 명)였으며, 무선 액세서리가 있는데도 불구하고 전혀 사용하지 않는 경우가 25.0\%(4명), '가끔(일주일에 몇 번)'과 ‘드 물게(한 달에 몇 번), 그리고 '아주 드물게(1년에 몇 번 정도)'가 각각 $6.3 \%(1$ 명)였다.

보청기의 부가 장치에 대한 질문에 음량 조절기가 있는 경우 가 $41.0 \%$ (48명), 음량 조절기를 선호하는 경우가 48.3\%(56명) 인 것으로 나타났다. 응답자 중 방향성 마이크 기능이 탑재된 경우는 $31.3 \%$ (35명)였다. 착용하고 있는 보청기가 디지털 보청 기라고 답한 경우가 83.8\%(98명), 아날로그 보청기라고 답한 경 우가 $1.7 \%$ (2명), 본인이 착용한 보청기가 어떤 신호 처리 방식인 지 모르는 경우가 $13.8 \%(16$ 명)였다.

보청기의 기능에 대한 만족도를 조사하기 위해 보청기의 착 용감, 음질, 관리의 편리함, 소리의 편안함 등에 관한 22개 세부 항목에 대하여 만족도를 조사하였다. 보청기의 관리 및 착용에 관한 질문에서 가장 만족도가 높은 항목은 '전반적인 착용의 편안함'으로 $68.4 \%$ (80명)가 만족한다고 응답하였으며, 가장 만 족도가 낮은 항목은 '배터리 사용 시간'으로 $23.7 \%$ (34명)가 만 족한다고 응답하였다(Figure 3).

보청기의 음질에 관한 12 개의 조사 항목 중에서 가장 만족 도가 높은 항목은 '청력의 개선'으로 $65.5 \%$ (76명)가 만족한다고 응답하였고, 가장 만족도가 낮은 항목은 '소음 속 청취'로 $38.7 \%$ (46명)가 만족한다고 응답하였다(Figure 4).

보청기를 적합한 사람을 묻는 질문에 85.3\%(99명)가 '청능사' 가 적합하였다고 응답하였고, 적합한 사람의 자격을 모른다는 응답이 $6.0 \%$ (7명), '청각사'가 $3.4 \%$ (4명), '이비인후과 의사'가 $1.7 \%$ (2명)가 적합하였다고 하였고, 보청기센터가 아닌 다른 경 로로 보청기를 구매하여 본인이 직접 적합하였다는 응답이 $0.86 \%$ (1명)였으며, 기타로 $2.6 \%$ (3명)가 보청기센터 직원이 적합 하였다고 응답하였다.

보청기 적합 및 서비스를 제공한 센터에 대한 만족도 질문 7개 항목 중 '직원의 친절도'가 가장 높은 94.9\%(111명)로 나타났으 며, ‘보청기 착용으로 인한 기대 효과에 대한 설명'이 81.0\%(94명) 로 가장 낮은 정도의 서비스로 응답하여 제공한 센터의 전반적 인 만족도는 높은 수준인 것으로 나타났다(Figure 5).

청각전문가로부터 사용법 및 관리 요령을 습득하는 데 어느 정도 시간이 소요되었는지 질문하였을 때 30 분과 1 시간 정도 소요되었다는 응답이 $47.5 \%$ (56명)와 $41.5 \%$ (49명)로 $89.0 \%$ 의 비율을 차지하였다. 그 외 2시간 이상이 $5.1 \%(6$ 명), 2시간이 
$3.4 \%$ (4명), 전혀 교육을 받지 않았다는 응답도 $2.5 \%$ (3명)인 것 으로 나타났다.

보청기 착용자들이 청력손실 때문에 의사소통 기술의 부족 으로 발생하는 부정적 감정의 관리에 대해 청각전문가가 얼마 나 많은 시간을 할애하였는지 질문하였다. 30 분과 1 시간이 각
각 $49.6 \%(57$ 명)와 $33.0 \%$ (38명)로 대부분을 차지했으며, 2시간 이상과 3시간 이상이 각각 $6.1 \%$ (7명)와 3.5\%(4명)였고, 이러한 서비스를 받지 못한 응답도 7.8\%(9명)로 나타났다.

보청기를 처음 착용하게 되면 그동안 난청으로 인해 듣지 못 하던 소리를 갑자기 듣게 되므로 일정 기간 동안 보청기를 통

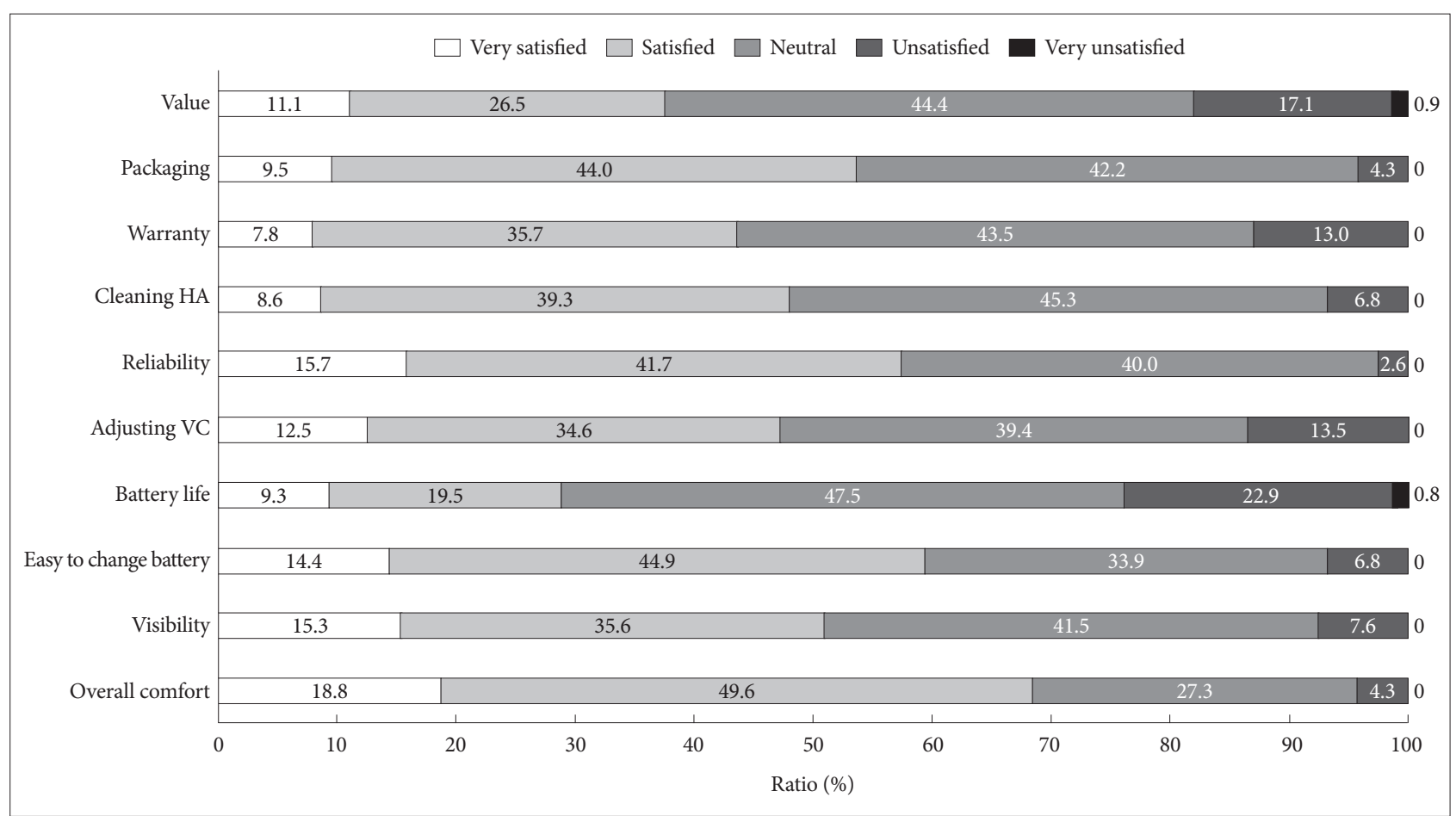

Figure 3. The satisfaction rate of factors for HA handling. HA: hearing aid, VC: volume control.

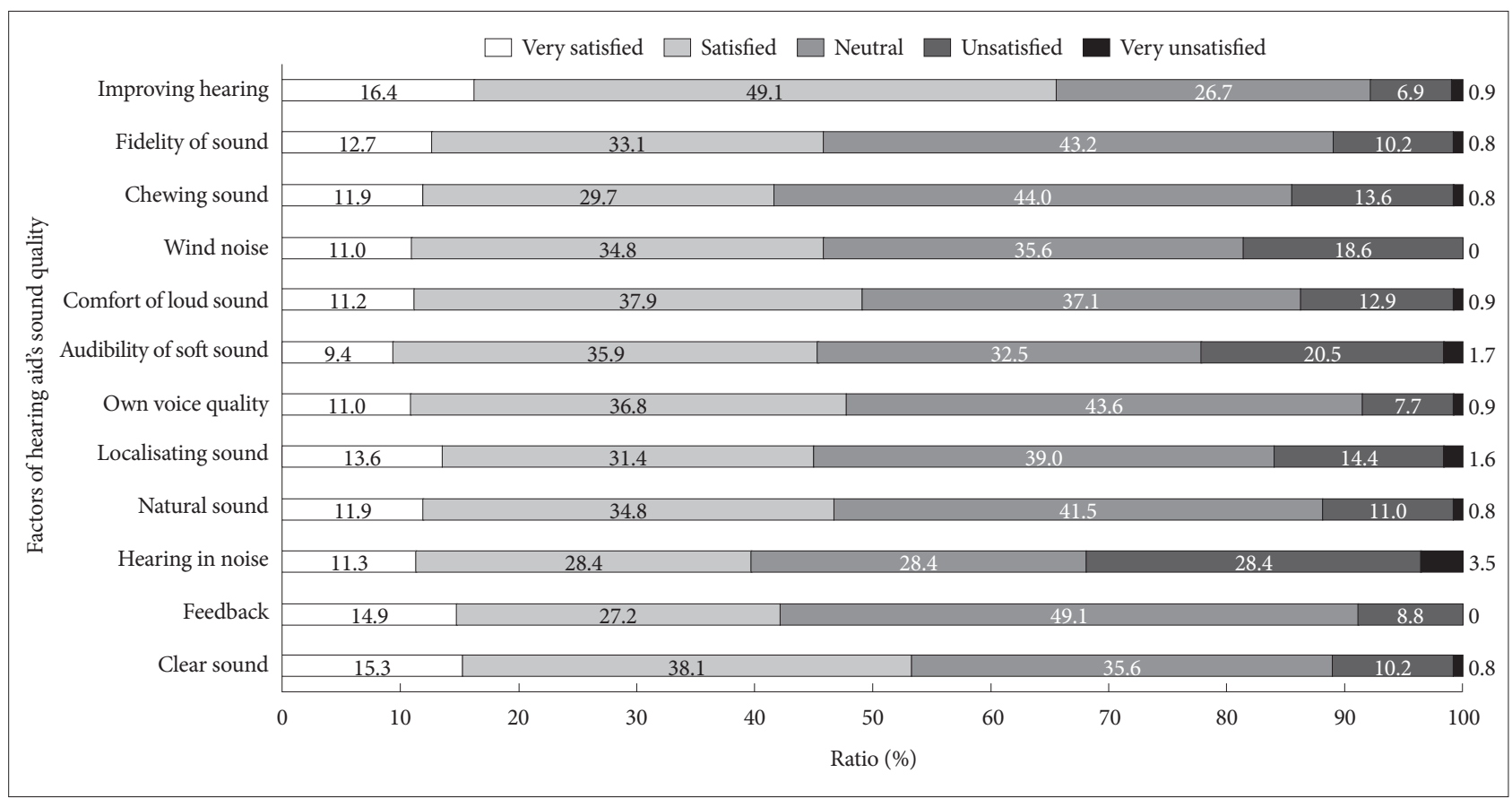

Figure 4. The satisfaction rates of sound quality factors for the individual hearing aid. 


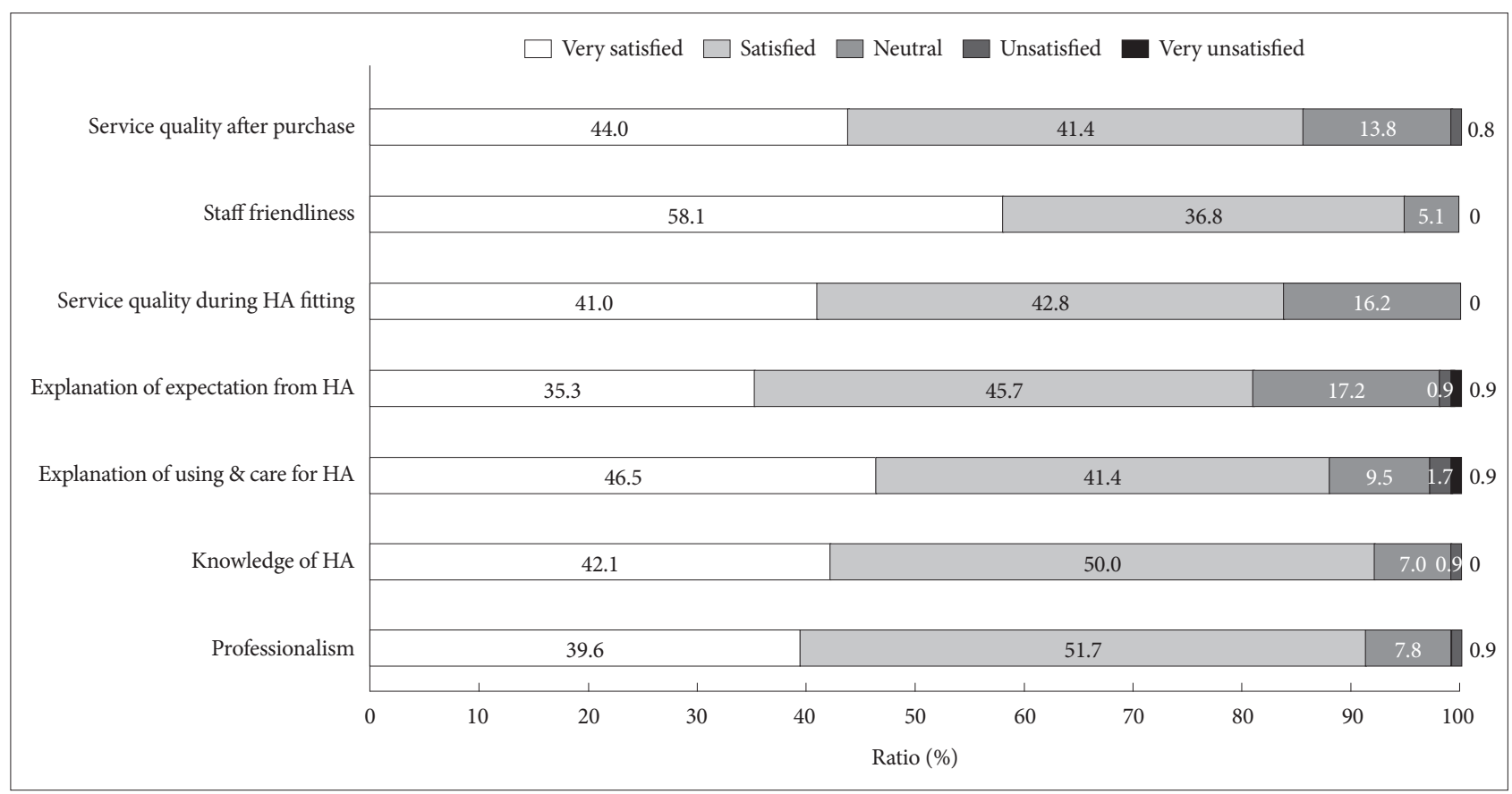

Figure 5. The satisfaction rates for the various factors of service quality provided by the HA centers. HA: hearing aid.

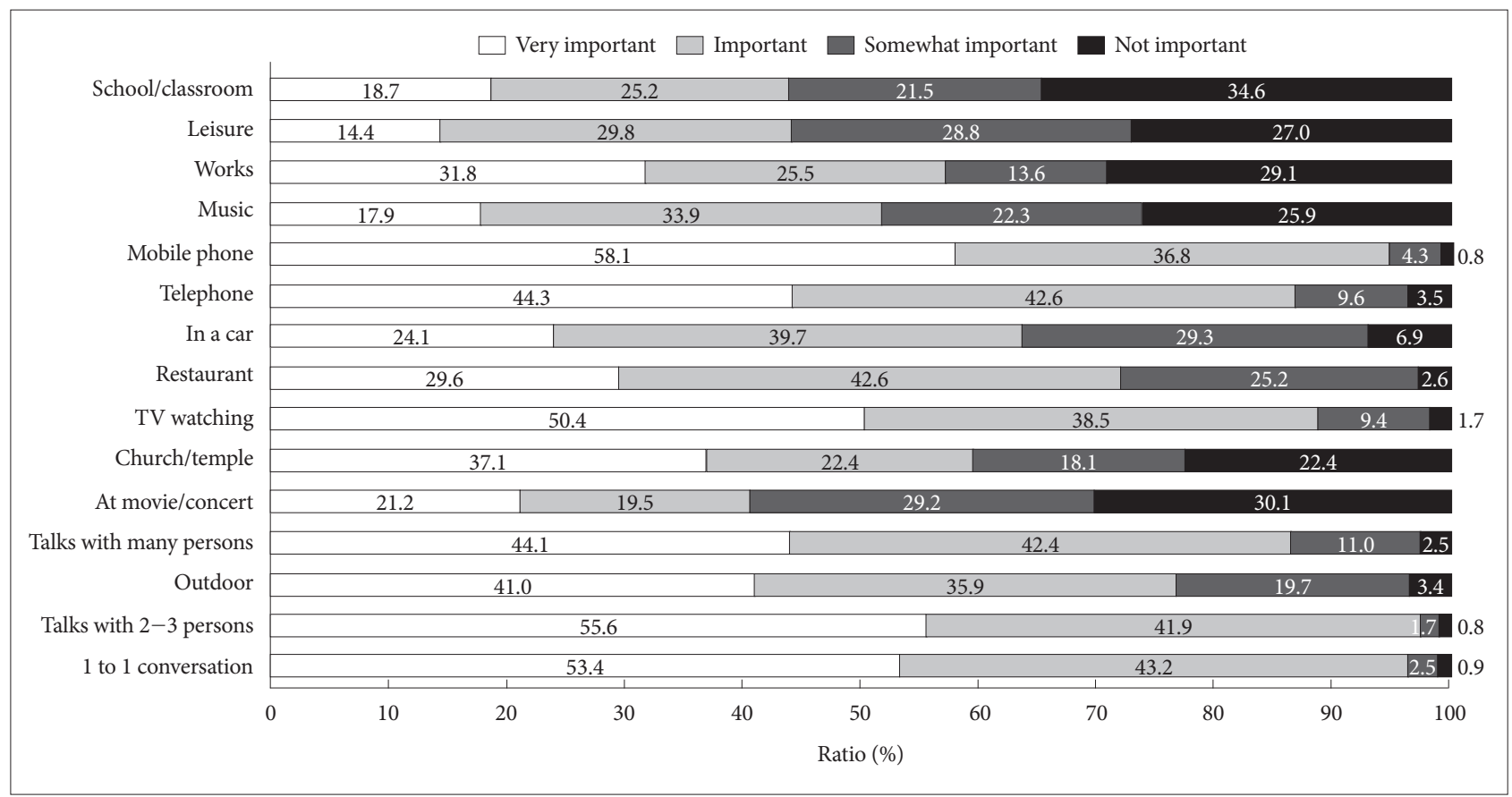

Figure 6. The ratio of importance of hearing in various listening situations for the hearing aid users.

해 듣는 것에 익숙해지는 순응(acclimatization) 기간이 필요하 다(Cox et. al., 1996). 순응 기간 동안 얼마나 자주 청각전문가 의 서비스를 받았는지 질문하였을 때 5 회 이상 서비스를 받았 다는 응답이 $47.4 \%$ (55명)로 가장 많았고, 3회가 24.1\%(28명), 4 회가 12.9\%(15명), 2회가 9.5\%(11명), 1회가 3.4\%(4명)로 나타났 다. 아직도 순응이 안 되었다는 응답도 $2.6 \%$ (3명)였다. 순응이
아직 안 되었다는 응답자 3 명의 보청기 착용 경험은 1 년이 2 명 이었고, 6 개월이 1 명이었다.

보청기의 배터리 교체나 청소와 같이 보청기 사용에 숙달되 기 위해 청각전문가를 방문한 횟수는 5 회가 가장 많은 $33.0 \%$ (37명)였고, 3회가 20.5\%(23명), 2회가 19.6\%(22명), 4회가 13.4\% (15명), 1 회가 $11.6 \%(13$ 명), 아직 숙달이 안 된 경우가 $1.8 \%(2$ 명) 
였다.

보청기 기술을 향상시키기 위해서는 보청기 착용자의 듣기 욕구와 필요성이 고려되어야 한다. 보청기 착용자에게 일상생 활의 청취 환경 중 가장 중요하게 생각하는 듣기 환경을 질문 하였을 때, 여러 청취 환경 중 '휴대폰 통화'가 가장 중요하다고 $58.1 \%$ (68명)가 응답하였고, 그 다음은 '2 3명과의 대화'가 $55.6 \%$ (65명), '일대일 대화'가 53.4\%(63명) 순으로 나타났다. 반 면 듣기 중요도가 높지 않은 청취 환경으로는 '학교나 교실 환 경'이 34.6\%(37명), '영화관이나 콘서트장'이 30.1\%(34명), '직장 이나 회사'가 29.1\%(32명) 순으로 나타났다(Figure 6). 15개의 청취 환경에 대한 보청기의 만족도를 분석하였을 때 '일대일 대 화' 상황이 '매우 만족'과 '만족' 응답을 합하여 78.4\%(91명)로 가장 만족스러운 청취 환경으로 나타났고, 그 다음으로 '휴대 전화 통화'가 65.6\%(76명), ‘TV 시청’이 62.2\%(72명) 순으로 나 타났다. 반면 보청기를 착용하고도 만족하지 못하는 청취 환경 은 '많은 사람과의 대화' 환경으로 27.6\%(32명)만이 만족한다고 응답하여 가장 낮은 만족도를 보였다.

보청기를 착용하지 않았을 때 소음이 있는 곳에서 대화의 어 려움의 정도에 대한 질문에 '많이 어렵다'가 $36.2 \%$ (42명), '다소 어렵다'가 27.6\%(32명), '매우 어렵다'가 25.9\%(30명)로 89.7\%가 어렵다고 응답하였고, '약간 어려움은 7.8\%(9명), '전혀 어렵지 않음은 $2.6 \%$ (3명)가 응답하였다.

보청기 착용이 특정 환경에서 듣기 능력을 어느 정도 개선하 는지 확인하기 위해 20 개의 특정 환경에서 보청기를 착용하였 을 때와 착용하지 않았을 때의 듣기 능력을 파악하고자 '이해 할 수 있다'의 긍정적 질문과 '어려움이 있다'의 부정적 질문으 로 구분하여 조사하였다. 예를 들어 긍정적인 질문으로 '나는 교회(혹은 성당이나 사찰)에서 설교(혹은 강론이나 설법)를 이
해할 수 있다'의 항목은 보청기를 착용하지 않았을 때보다 착 용하였을 때 $33.9 \%$ 로 가장 높은 개선율을 보였고, '나는 강당 과 같이 큰 공간에서 멀리 있는 사람이 말하는 단어를 이해할 수 있다'의 항목은 $26.2 \%$ 로 가장 낮은 개선율을 보였다. 부정적 인 질문의 예로 '나는 에어컨이나 선풍기가 켜진 상황에서 다른 사람의 말소리를 이해하는 데 어려움이 있다에 보청기를 착용 하였을 때 $22.3 \%$ 가, '나는 강연을 들을 때 많은 정보를 놓친다' 에 7.4\%가 보청기 착용이 도움이 되는 것으로 나타났다.

보청기 사용 이후 개선된 삶의 질에 대하여 질문하였다. 보청 기 착용 이후 ‘의사소통 능력의 개선’에 $91.1 \%(103$ 명)가 가장 긍 정적인 삶의 질에 대한 변화가 있는 것으로 나타났다. 가장 개 선되지 않은 삶의 질 부분은 '육체적 건강'으로 $47.3 \%$ (53명)가 응답하였다(Figure 7).

청각 보조기기를 사용한 경험이 있을 경우, 도움이 된 기기 를 모두 선택하도록 하여 다중 응답이 가능하도록 한 질문에 음성 증폭기 5.9\%(7명), 자막 기능 3.4\%(4명), TV 증폭 헤드셋 $2.5 \%(3$ 명), 전화 증폭기 $1.7 \%(2$ 명)가 응답하였고, 구매 장소로 는 보청기센터가 6 명, 의료기기 판매점이 2 명, 인터넷 구매가 1 명, 기타가 1 명이었다.

여러 청취 환경에서 보청기나 청각 보조기기의 도움 없이 듣 고 이해할 수 있는 수준에 대한 질문에 조용한 방에서 속삭이 는 소리를 듣는 것이 불가능하다고 응답한 경우가 $77.7 \%(87$ 명), 다른 방에서 보통 목소리로 말하는 것을 듣는 것이 불가능 하다고 응답한 경우가 83.2\%(94명), 다른 방에서 큰 소리로 이 야기하는 것을 듣는 것이 불가능하다고 응답한 경우가 $55.3 \%$ (63명)였다. 좋은 귀에 크게 말하면 이해가 가능한지 묻는 질문 에 응답 순위는 '큰 소음은 들을 수 있다', '보청기나 청각 보조 기기가 없으면 소음 속에서 소리를 구별할 수 없다', '소리를 듣

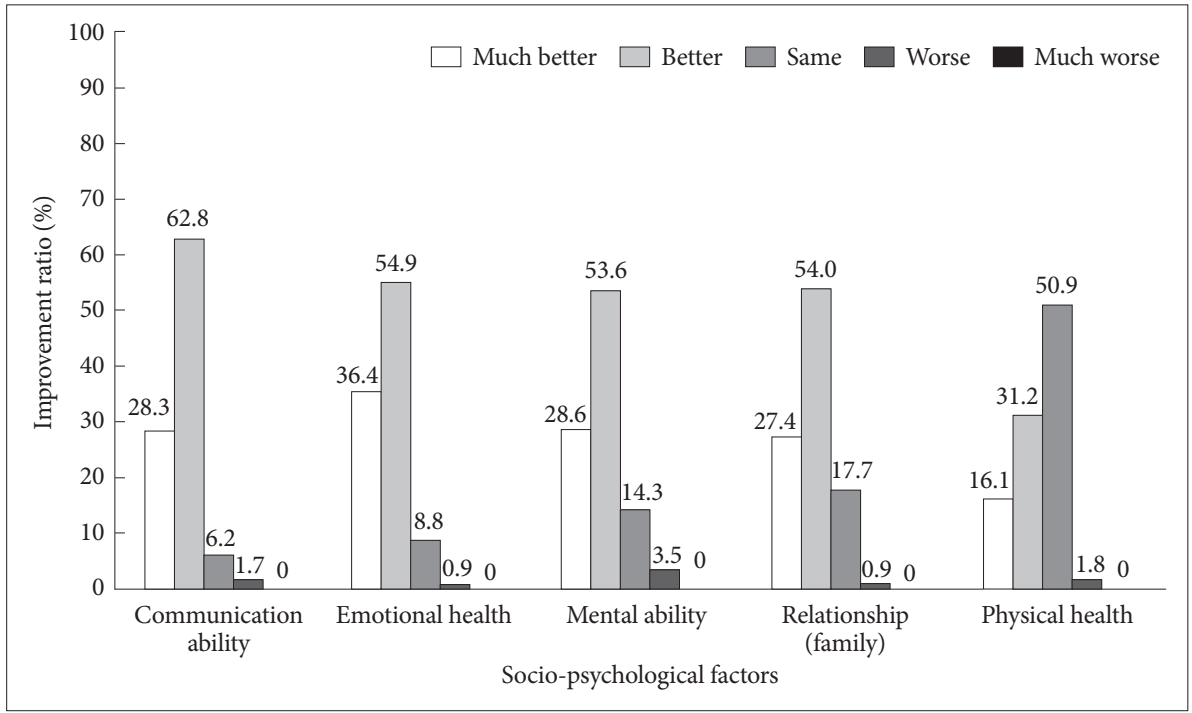

Figure 7. The ratio of improvement of socio-psychological factors after wearing hearing aids $(\%)$. 
고 소음의 종류를 구별할 수 없다' 순으로 87.7\%(100명), 85.1\% (97명), 69.6\%(78명)의 응답률로 나타났다.

향후 보청기를 구매할 계획에 대한 질문에 향후 4년 이내 구 매 계획이 없다는 응답이 $34.5 \%$ (39명)로 가장 많았고, 4년 이내 구매 계획이 있는 경우가 $32.7 \%$ (37명), 3년 이내가 $10.6 \%(12$ 명), 2년 이내와 1년 이내가 각각 8.0\%(9명)씩, 6개월 이내가 6.2\%(7 명)여서 4년 이내에 구매하고자 하는 경우가 총 $65.5 \%$ 였다.

\section{DISCUSSIONS}

본 연구는 국내 보청기 착용자의 만족도를 파악하는 것을 주 목적으로 하고 있지만 기존 설문 체계와 달리 청각학적 요인 이나 보청기에 관련된 전문적인 사항에 대해서는 청각전문가가 직접 작성하게 하여 고령의 보청기 착용자들이 잘못 작성할 수 있는 기회를 줄여 응답의 오류율을 감소시키고 좀 더 전문적이 고 객관적인 비교 분석이 가능할 수 있도록 하였다. 예를 들어 청각전문가가 작성한 현황에 따르면 보청기 사용자의 난청의 정도는 중도 난청이 22.3\%(51귀), 중고도 난청이 41.7\%(93귀), 고도 난청이 $25.1 \%(56$ 귀)로 청력검사 결과에서 나타났으나, 보 청기 착용자가 생각하는 자신의 난청의 정도에 대한 평가는 중 도 난청이 $49.6 \%$ (56명), 고도 난청이 $39.8 \%(45$ 명)로 나타나 난 청의 정도에 대한 개인적인 평가는 청력검사 결과와 다른 것으 로 나타났다. 이와 같은 맥락에서 MarkeTrak이나 EuroTrak 보고서에서는 난청자가 보청기 착용을 하게 된 주요한 동기가 '본인의 청력이 나빠졌다'고 느꼈을 때라고 보고하고 있는 점을 고려할 때, 난청자가 난청의 정도 및 유형 등에 대해 충분히 이 해할 수 있는 쉽고 구체적인 정보 제공이 필요할 것으로 생각 된다(Abrams \& Kihm, 2015; EHIMA, 2019). 특히, 고령자에 게는 난청과 동반된 치매 발생 확률의 증가와 낙상 위험이나 우울증의 증가와 같은 연관된 질환의 발생에 대한 위험성에 대 한 정보도 추가적으로 제공하는 것이 필요할 것으로 생각된다 (Dawes et al., 2015; Gurgel et al., 2014).

최근 출시되는 보청기는 빠르게 변화하는 IT 기술을 접목하 여 여러 청취 환경에서 적용할 수 있는 다양한 기술 개발이 이 루어지고 있다. 특히 무선 기술이나 스마트폰과의 접목을 통해 보청기의 활용 범위가 확대되어, 기존 보청기로 청취하기 어려 웠던 환경에서도 보청기 착용자는 도움을 받을 수 있게 되었다. 그러나 본 연구 결과는 $13.8 \%$ 만이 무선 액세서리 기술을 사용 하고 있는 것으로 나타나 이런 첨단 기술의 보급률이 아직 낮 은 것으로 나타났다. 그 이유로는 첫째, 현재까지 기술 개발의 결과로는 무선 기술이 일부 ITC형, BTE형, RIC형 보청기에만 적용이 가능하여 고막형(IIC, $\mathrm{CIC}$ ) 보청기와 같은 소형 보청기 를 선호하는 국내 보청기 착용자에게 관심을 받지 못하기 때문
이고, 둘째, 이러한 기능들의 장점에 대한 적극적인 소개나 홍 보가 부족하여 보청기 착용자들이 첨단 기술을 경험할 기회가 적기 때문이며, 셋째, 보청기 착용자들이 보청기 이외의 부가적 인 장치를 보유하거나 조절하는 데 미숙하고 불편함을 느껴 추 가적인 비용을 지불하고 구매하기를 꺼려하기 때문으로 생각된 다. 더욱이 본 연구에서 보청기가 삶의 질을 개선하는 측면에서 의사소통 능력의 개선에 $91.2 \%$ 가 긍정적인 변화를 주었다고 응답한 결과를 고려할 때, 더 많은 보청기 착용자가 최신 무선 액세서리를 활용한다면 다양한 음향기기나 첨단 의사소통 기 기들을 통해 삶의 질 개선에 긍정적 영향을 줄 것으로 생각된 다. 이를 위해서 청각전문가는 무선 액세서리의 활용에 대한 교 육과 이를 활용한 청능재활 서비스를 적극적으로 제공해야 한 다고 생각한다.

본 연구에서 착용하고 있는 보청기 타입에 대한 조사에서 보 청기 착용 형태는 귓속형 보청기는 $77.9 \%$ 로 높은 비율을 보였 으나 RIC형 보청기는 불과 $19.5 \%$ 의 비율을 차지하는 것으로 나타났는데, 이는 선행연구에서 귓속형 보청기의 판매 비율이 $\mathrm{RIC}$ 형이나 BTE형에 비해 높은 결과와 일치한다 $(\mathrm{Sim} \& \mathrm{Kim}$, 2019). 이러한 결과는 미국에서 판매되는 보청기 착용 형태의 비율과는 다른데, 2019년 조사에서 RIC형 보청기의 판매 비율 이 2018년의 $72.5 \%$ 보다 $4.1 \%$ 증가한 $76.6 \%$ 를 차지하고 있다. 또 한 이러한 RIC형 보청기의 판매 비율이 증가되는 현상은 앞으 로도 지속될 것으로 예상하고 있다(The Hearing Review, 2019). 보청기 착용 형태의 차이는 본인의 목소리 음질에 대한 만족도 조사 결과와 관련 있는 것으로 생각된다. RIC형 보청기의 착용 률이 높은 미국은 본인의 목소리 음질에 대한 만족도가 $73 \%$ 로 높지만 본 연구에서는 $47.9 \%$ 로 낮은 만족도를 보이기 때문이다 (Kochkin, 2010).

본 연구에서는 착용하고 있는 보청기의 모델명을 청각전문가 가 기록하게 하여 보청기 기술 수준을 최고급형, 고급형, 기본 형, 경제형까지 네 단계로 구분하여 보청기 착용자의 만족도에 미치는 영향을 분석한 결과 보청기의 기술 수준이 전반적인 만 족도에 영향을 미치지 않는 것으로 나타나 보청기의 기술 수준 은 전기 음향학적 측정이나 검사실 환경에서의 측정에서는 단 계별로 차이를 보이지만 보청기 착용자는 그 차이를 느끼지 못 하는 것으로 나타났다. 이는 생태 순간 평가(ecological momentary assessment)를 바탕으로 한 스마트폰을 활용한 최근 연구(Palmer, 2019)에서 실생활적인 측면에서 보청기 착용자가 보청기의 기술 수준을 느끼는 차이점은 크지 않다는 연구 결과 와 일치한다. 그러나 보청기 만족도에 영향을 끼치는 요인 중 보 청기 성능의 영향이 크다는 다른 연구자(Wong et al., 2009)의 보고와는 상반되는 결과여서 보청기의 기술 수준이 만족도와 연관이 없다고 단정적으로 결론 내릴 수는 없다. 이에 대해서는 
추가적인 연구가 더 이루어져야 할 것으로 생각한다.

본 연구 결과에서 보청기의 한 대당 평균 구매 가격은 182 만 원으로 나타났는데, 이는 국내 보청기센터를 중심으로 한 선행 연구(Sim \& Kim, 2019)의 결과인 150만원대 보다는 조금 높 고, 대학병원의 이비인후과를 내원한 보청기 착용자를 대상으 로 한 조사(Ahn et al., 2010) 결과인 265만원보다는 낮은 것으 로 나타났다. 또한 일본의 평균 구매 가격은 $¥ 150,000$ 이고, 미 국의 평균 구매 가격은 $\$ 2,372$ 로 조사되어 보청기의 판매 가격 은 국내외에서 아직 일관된 자료로 제시할 수 없는 것으로 결 론 지을 수 있다(EHIMA, 2019; Strom, 2018).

보청기 착용자의 만족도 현황은 본 연구에 참여한 보청기 착 용자의 전반적인 만족도가 $64.4 \%$ 로 나타나 2014년에 실시한 조사의 $60.8 \%$ 보다 약간 상승한 것으로 나타났다(Chang et al., 2014). 이를 외국의 보청기 만족도와 비교할 때 일본의 $38 \%$ 보 다는 높고, 독일의 $76 \%$ 나 미국의 $81 \%$ 보다는 낮은 것으로 나타 났다(Abrams \& Kihm, 2015; EHIMA, 2019). 이렇게 나라마 다 서로 다른 만족도를 보이는 데는 이유가 여러 가지 있을 수 있지만, 일본보다 월등히 높은 만족도를 나타낸 이유로는 첫째, 국내 보청기 착용자의 양이 착용 비율이 $62.4 \%$ 로 일본의 $45 \%$ 에 비해 높고, 둘째, 국내에서 청각전문가의 보청기 적합, 상담, 사후 관리 등의 보청기 관리 서비스 질에 관한 국내 만족도가 81.0 94.9\%이지만 일본은 59 62\%이고, 셋째, 국내 청각전문 가의 높은 질적 수준이 전반적인 보청기의 만족도에 영향을 준 것으로 생각된다. 이는 특히 상대적으로 전문가 과정이 설립되 지 못하고 있는 일본의 미비한 교육 제도의 영향이라고 생각할 수 있다(Lee, 2006; Sim \& Kim, 2019). 국내 보청기 착용자는 85.3\%가 전문적인 교육과 자격 시험을 통과한 청능사가 보청기 를 상담 및 적합하였다고 응답하였으나, 일본은 44\%만이 공인 된 보청기 기술자(certified hearing aid technician)가 적합하였 다고 응답하여 청각전문가의 역할에 대한 차이가 보청기 착용 의 만족도에도 영향을 준 것으로 볼 수 있다(EHIMA, 2019). 그 러나 본 연구에 참여한 보청기센터의 다수가 청능사 자격증을 보유하고 있어 적합의 전문성과 교육의 정도가 편중되어 일본 의 보청기 전문가의 전문성과 단순 비교는 한계성이 있다. 추후 더 폭넓은 연구를 통해 확인할 필요성이 있으나 보청기 전문가 의 교육제도의 차이가 영향을 미칠 수 있는 점은 명백한 것으 로 생각한다.

국내외의 보청기 구매에 대한 정부의 경제적 지원 정책은 일 정 정도 이상의 청력손실이 있을 경우 보청기 구매 시 일정 금 액을 정부에서 지원해 주거나, 정부에서 보청기를 일괄 구매하 여 지원하거나, 개인 보험에서 지원해 주는 등 국가에 따라 다 양한 제도가 있다. 우리나라는 청각장애 등급을 받은 사람에 게 5 년마다 1 회씩 최대 131 만원까지 보조기기 구매 보조금을
지원하는 제도가 2015년 11월 15일부터 시행되고 있다(National Health Insurance Sharing Service, 2018). 본 연구의 보청기 착용자 중에는 보조기기 보조금 혜택을 받아 구매한 경우가 $49.1 \%$ 였으나, 일본의 경우 $12 \%$ 만이 혜택을 받은 것으로 보고하 였고, 독일의 경우 94\%가 혜택을 받고 있으며, National Hearing Service에서 보청기를 일괄 구매하여 지급하는 영국의 경 우는 $75 \%$ 가 혜택을 받은 것으로 보고하여 국내 보청기 착용자 의 혜택은 일본보다는 높지만 유럽의 복지 선진국가에 비해서 는 낮은 것으로 나타났다(EHIMA, 2019).

본 연구의 보청기 관리 및 기능에 대한 조사에서 가장 낮은 만족도를 보인 항목은 보청기 배터리 수명으로 $23.7 \%$ 만이 만 족한다고 나타나 일본의 $29 \%$ 와 유사하였으나 영국의 $71 \%$, 독 일의 $62 \%$ 보다는 매우 낮게 나타났다(EHIMA, 2019). 이러한 현상에 두 가지 이유를 생각해 볼 수 있는데, 첫째, 국내 보청기 착용자는 귓속형 보청기의 착용률이 높아 상대적으로 용량이 작은 보청기 배터리를 주로 사용하기 때문이고, 둘째, 최근 출 시되는 충전형 보청기 배터리 기술이 RIC형과 BTE형에만 탑 재되어 RIC형 보청기의 보급률이 낮은 우리나라에서 이러한 최신 기술의 혜택을 못 받기 때문이다.

지금까지 보청기 만족도 관련 연구는 주로 보청기 착용자의 개인적 측면에 중점을 두거나 보청기의 기능에 관한 연구로 설 문지를 통해 만족도를 파악하는 수준이었지만, 최근에는 실생 활에 밀접하고 진보된 만족도 평가 방법 중의 하나인 생태 순간 평가 등이 제시되고 있다(Palmer, 2019). 이러한 최신 평가 방법 을 적용하고 유럽의 EuroTrak이나 미국의 MarkeTrak과 같이 구 체적인 보청기 시장의 실정과 보청기 사용자의 다양한 현황을 잘 반영하는 체계적인 설문지 개발이 필요한 것으로 생각한다.

이를 위해 본 연구는 앞서 개발되고 검증된 도구인 MarkeTrak 8권을 기반으로 설문지를 재구성하여 국내의 보청기 만족 도와 현황을 조사하고 그 결과를 외국의 현황과 비교 고찰하였 다. 이러한 연구 과정에서 나타난 한계점과 문제점들을 확인하 였고 이러한 부분을 개선하여 우리나라 실정에 맞는 보청기 만 족도 및 시장 조사 프로그램 개발이 필요하다. 특히 본 연구 과 정에서 나타난 150 개 항목의 방대한 설문 내용은 보청기를 주 로 착용하는 고령층이 모두 답하기에는 너무 길기 때문에 집중 력이 흐려질 수 있고 적절한 응답을 구하는 데 어려움이 있어 중복되거나 국내 현실과 맞지 않는 항목을 삭제하고 축소할 필 요성을 확인하였다. 또한 우리나라의 현황을 반영하기 위해 보 조기기 보조금 제도에 대한 질문이나 보청기 자격증 관련 견해 와 인식에 대한 질문을 추가하고 국내 보청기 착용자가 주로 사용하는 보청기 기능에 관한 문구를 추가하는 등 우리나라 실정에 맞는 설문지 개발의 필요성을 확인하였다. 앞으로 우리 나라도 체계적으로 개발되고 구축된 보청기 적합 시스템을 지 
속적으로 활용하여 자료를 축적하고 이를 바탕으로 보청기 착 용자에게 실질적으로 도움이 되는 정책 개발과 청능재활 서비 스 체계를 갖추어 궁극적으로 보청기 착용자의 만족도와 착용 률이 복지 선진국과 같이 향상되기를 기대한다.

중심 단어 : 보청기 만족도·보청기·보청기 시장·보청기 착용률.

\section{Ethical Statement}

This study was approved by the Institutional Review Board of Hallym University (IRB \#HIRB-2018-048).

\section{Acknowledgments N/A}

\section{Declaration of Conflicting Interests}

There are no conflict of interests.

\section{Funding N/A}

\section{Author Contributions}

All authors contributed equally to this work S.S., J.L., and J.K. designed and performed experiments, analyzed data, and wrote the paper; S.S. designed and performed experiments in the clinic; J.L., J.K., and S.S. provide statistical analysis and critical revision; Also, the authors discussed the results together and implications and commented on the manuscript at each stage.

\section{ORCID iDs}

Sangik Sim Jinsook Kim

\section{https://orcid.org/0000-0002-3345-299X} https://orcid.org/0000-0003-3440-2393

\section{REFERENCES}

Abrams, H. B. \& Kihm, J. (2015). MT9 Reveals Renewed Encouragement as well as Obstacles for Consumers with Hearing Loss. The Hearing Review. Retrieved from https://www.hearingreview.com/practice-building/ marketing/introduction-marketrak-ix-new-baseline-hearing-aid-market.

Ahn, J. H., Kim, Y. H., Suh, H. S., Shin, S. J., Jang, B. H., Song, H. J., et al. (2010). Analysis of Obstacle and Benefit of Hearing Aid Usage of Hearing Impaired Patient. National Evidence-Based Healthcare Collaborating Agency. Seoul: National Evidence-based Healthcare Collaborating Agency.

Chang, Y. S., Choi, J., Park, G. Y., Youm, H. Y., Byun, H. Y., \& Cho, Y. S. (2014). Evaluation of satisfaction with hearing aids using a questionnaire based on MarkeTrak survey. Korean Journal of Otorhinolaryngology-Head and Neck Surgery, 57(5), 304-313.

Cox, R. M., Alexander, G. C., Taylor, I. M., \& Gray, G. A. (1996). Benefit acclimatization in elderly hearing aid users. Journal of the American Academy of Audiology, 7(6), 428-441.

Dawes, P., Emsley, R., Cruickshanks, K. J., Moore, D. R., Fortnum, H., Edmondson-Jones, M., et al. (2015). Hearing loss and cognition: The role of hearing AIDS, social isolation and depression. PloS One, 10(3), e0119616. EHIMA. (2019). European Hearing Instrument Manufacturers Association. EHIMA. Retrieved from https://www.ehima.com/eurotrak/.

Erler, S. F. \& Garstecki, D. C. (2002). Hearing loss- and hearing aid-related stigma: Perceptions of women with age-normal hearing. American Journal of Audiology, 11(2), 83-91.

Gurgel, R. K., Ward, P. D., Schwartz, S., Norton, M. C., Foster, N. L., \& Tschanz, J. T. (2014). Relationship of hearing loss and dementia: A prospective, population-based study. Otology and Neurotology: Official Publication of the American Otological Society, American Neurotology Society [and] European Academy of Otology and Neurotology, 35(5), 775-781.

Jorgensen, L. E. (2016). Verification and validation of hearing aids: Opportunity not an obstacle. Journal of Otology, 11(2), 57-62.

Kochkin, S. (2010). MarkeTrak VIII: Consumer satisfaction with hearing aids is slowly increasing. The Hearing Journal, 63(1), 19-20, 22, 24, 26, $28,30-32$.

Korea Centers for Disease Control and Prevention. (2013). 5th National Health and Nutrition Assessment. KCDC. Retrieved from https:// knhanes.cdc.go.kr/knhanes/sub03/sub03_06_02.do.

Lee, M. S. (2006). Audiologists and the current status of audiology in Asia. Audiology, 2(1), 17-21.

Lee, S. H. \& Lee, S. H. (2010). A Study on the Causes of Low Fertility and Population Aging: Focusing on Economic Factors of Marriage Decision. Seoul, Bank of Korea.

National Health Insurance Sharing Service. (2018). The Status of Registered Assistant Device Companies for the Disabled. NHISS. Retrieved from https://nhiss.nhis.or.kr/bd/ay/bdaya001iv.do.

Palmer, C. (2019, July 1). Hearing Aids 2019: Today's Technology. ENT \& Audiology News. Retrieved from https://www.entandaudiologynews. com/features/audiology-features/post/hearing-aids-2019-today-s-technology.

Sawyer, C. S., Munro, K. J., Dawes, P., O’Driscoll, M. P., \& Armitage, C. J. (2019). Beyond motivation: Identifying targets for intervention to increase hearing aid use in adults. International Journal of Audiology, 58(1), 53-58.

Sim, S. I. \& Kim, J. S. (2019). A current status of centers and market for hearing aids in Korea. Audiology and Speech Research, 15(3), 183-195.

Strom. K. (2018). Will Hearing Aid Sales Top 4 Million Units in 2018? The Hearing Review. Retrieved from https://www.hearingreview.com/ hearing-loss/hearing-loss-prevention/industrial-military/will-hearingaid-sales-top-4-million-units-2018.

The Hearing Review. (2019). Hearing Aid Sales Increase by 2.5\% in First Quarter of 2019. The Hearing Review. Retrieved from https://www.hearingreview.com/hearing-loss/hearing-loss-prevention/industrial-military/hearing-aid-sales-increase-first-quarter 2019.

Wong, L. L., Hickson, L., \& McPherson, B. (2003). Hearing aid satisfaction: What does research from the past 20 years say? Trends in Amplification, 7(4), 117-161.

Wong, L. L., Hickson, L., \& McPherson, B. (2009). Satisfaction with hearing aids: A consumer research perspective. International Journal of Audiology, 48(7), 405-427.

Yoo, C. M., Jung, C. H., Kim, M. G., Heo, M. J., \& Park, S. G. (2012). A study on the perception of hearing aids according to hearing loss degree for the elderly in Busan. Journal of Speech-Language and Hearing Disorders, 21(2), 227-241. 